\title{
A Study of Computer Literacy Among Stm Teachers in Colleges of Education in Nigeria
}

\author{
Timothy Moses ${ }^{a, 1}$, Sani Yakubu ${ }^{b, 2}$
}

${ }^{a}$ Department of Computer Science, Federal University Lafia, Nasarawa State, Nigeria

${ }^{\mathrm{b}}$ Department of Educational Management, Nasarawa State University, Keffi, Nasarawa State, Nigeria

11visittim@yahoo.com*; ${ }^{*}$ syk@yahoo.com

\begin{abstract}
Information and Communication Technology has changed instructional conveyance. Advancement recorded in information assembling, teaching, and learning collection has given teachers new devices to work with, subsequently the upheaval in the field of training. This study examined computer literacy among Science, Technology, and Mathematics (STM) instructors in Colleges of Education. Discoveries show that the degree of computer proficiency among STM instructors is low. The explanation behind this incorporates few available skillful instructors, insufficient ICT tools in schools, computer phobia, access to Personal Computers (PCs)/PC labs, and absence of ICT devices for STM training. Proposals were anyway made that will help improve the degree of proficiency among STM instructors.
\end{abstract}

Keywords:

Computer literacy, STM, vocational and technical colleges, ICT tools.

This is an open access article under the CC-BY-NC license.

\section{INTRODUCTION}

One of the most significant deciding attributes of today's information technology era is that data is expanding at a pace too quickly to even think about catching up (Necdet, 2010). In an environment like this, it is important to make, create, and update the abilities of individuals in informationbased professions (Tomte et al., 2019). Otherwise, their expert abilities and status might be sketchy. Essential aptitudes of 'teachership', as one of these callings, should be "educators' showing capacity", "world knowledge" and "subject knowledge". Abilities in each of these regions change continually and can never again be pre-administration training.

The usage of the word literacy has a profound history in the United States as it identifies with improving individuals' capacities to listen, read, and compose utilizing the English language (Mary, 2007). Literacy movement has utilized formal and informal instructional procedures with the express expectation to assist people to assemble core knowledge and aptitudes of communication that will assist individuals accomplish the full rights and advantages of citizenship. After some time, the word literacy was used by various 
communities to depict a more extensive scope of human characteristics identified with sociocultural phenomena (e.g., social proficiency), innovations in technology (e.g., media, PC, and digital literacy), and competency domain (e.g., Microsoftliterate). To be computer literate, therefore, is to have the capacity to utilize PCs and relevant innovation productively, with a scope of aptitudes covering levels from basic use to cutting edge critical thinking (Haigh, 1985). Looking at computer literacy from another perspective, the understanding of programming language and how PCs work (Tomte et al., 2019). This paper plans to take a look at computer literacy among educators of Science, Technology, and Mathematics (STM) in colleges of education. The paper is divided into seven sections. Section two reviews works of literature on computer literacy among STM educators while section three studies of computer literacy among STM teachers in colleges of education in Nigeria. Section four is the methodology and section five gives a summary of findings and possible reasons for low PC proficiency among STM teachers. Sections six and seven are the conclusion and recommendations respectively.

\section{LITERATURE REVIEW}

The computer is of extraordinary assistance, providing a platform to create and transfer any sort of data. Right now, getting the fundamental data completely and on schedule; utilizing the retrieved information in personal and professional turn of events, and accordingly turning into a successful instructor is on the whole straightforwardly identified with the competency to utilize the PC adequately (Necdet, 2010). Even though no shortcoming of their own, most instructors are not prepared to teach using a PC because, they got their training (BC) before computers were invoked. Presently, they're finding that, they need PC proficiency as a feature of their occupations (Necdet, 2010). It is hence simple to infer that computer literate people will receive more prominent rewards than their partners who do not have that skill (Satharasinghe, 2006). In obtaining data, making learning and showing process increasingly powerful, the alleged aptitudes of instructors, identified with PCs, are depicted as "computer literacy". This term implies more than 'readers' and 'writers' in the world of computers. These days, the expression, 'electracy' is preferred to be used instead of 'computer literacy' (Ulmer, 2003). As indicated by Ulmer (2003), electracy is to computerized media what education is to 
print, and is altogether not quite the same as instruments will enhance STM education. the articulation 'computer literacy'. The advantages of information technology Electracy depicts the sort of education or for students can be boundless, especially on ability important to utilize the full the off chance that they become dynamic informative capability of new electronic makers, ready to participate in the learning. media such as multimedia, hypermedia, ICT instruments can have a significant social programming, and the virtual world while PC proficiency requires some comprehension of PC programming and how PCs work. The reason for this paper is to decide the degrees of STM instructors' PC proficiency, which is significant in obtaining data and making learning increasingly compelling. To comprehend the degree of PC proficiency among STM educators in this manner, it is imperative to recognize what ICT instruments are utilized in STM instruction. This will empower us to have a smart thought fair and square of ICT proficiency among instructors. The following sub-segment thusly looks to analyze ICT devices and STM education.

\section{ICT TOOLS AND STM EDUCATION}

Technology is a significant segment of every instructing and learning form associated with education. This is particularly valid if we desire an "allencompassing change of teaching in today's digital technology" (Balanskat et al., 2006). Classroom rehearsals impact students learning (Barak, 2014) therefore, it is critical to contemplate and see how ICT effect on the numerous aspects of STM training, for example, adding to instructor capabilities, expanding the learning assets, expanding student and educator inspiration. In this section, we investigate three kinds of ICT instruments that can help in STM education. These instruments are collaborative tools, online learning, digital and adaptive content. For every one of these classifications, we share a couple of instances of tools, clarify their utilization in STM training, their consequences for students and instructors, and also give a few proposals or instances of good practices.

\section{Collaborative tools}

"Collaborative learning" is a collective term for several instructive methodologies including joint scholarly exertion by students and educators (Berenfeld and Yazijian, 2010). Educators' convictions and perspectives affect the learning techniques and procedures they use (Correll, 2015). ICT-upgraded learning is seen as the outcome of ICT support in teaching while involving students in dynamic, intuitive, and collaborative learning that brings about 
students' increasingly significant and profound learning.

From the perspective of learning and premium, the utilization of ICT includes inspirational learning highlights for students who take part in collaborative work (Davis, 2003). These devices permit students' increasingly broad choices of assets, support arrangement, and surveying ones' activities, just as offer determination of assignments. Innovation can be used to participate in cooperative learning; coarranging and various activities that help students feel near their companions. Collective instruments additionally empower coordinated effort with specialists a good ways off.

\section{Example of tools}

Enormous scope instruments with the likelihood to share reports or make records include Microsoft Office, Google Docs, and Microsoft One Drive. Distributed computing innovation can help instructors and students cooperative work and encourage overall connections. Skype video meetings over the internet for example, might be utilized for presentations, exhibitions, and to empower intelligent collaborative learning. Skype in the classroom site encourages instructors to set up virtual field trips, plan online master conversations, and e-learning. Various tele- community-oriented undertakings similar to the Global Learning and Observations to Benefit the Environment (GLOBE), join students and educators of various levels of learning in leading earth science research.

2. Online Learning

The extent of internet learning in instruction is very wide going from student quiz-taking in especially hard topics (Adesoji et al., 2019) to students following formal or informal courses online on a specific STM subject. A similar decent variety applies to educators. As indicated by UNESCO, "proficient learning" corresponds to the extra abilities and information which instructors obtain in their work, beyond what they figured out how to become qualified educators (Dawson, 2012).

Computerized aptitudes for educators and students that can be created utilizing electronic learning include digital citizenship, which involves having the ICT equipment and abilities to take part in an advanced society. For instance, to get to government data on the web, to utilize social networking sites, and to utilize a cell phone; Computerized education - essential PC abilities, for example, having the option to do word-preparing or go on the web. Furthermore, computerized ability prerequisites are going past advanced 
citizenship and literacy to include computational reasoning and more elevated software engineering aptitudes.

\section{Example of tools}

Computerized proficient improvement assets, for example, TeachScape and Knowledge Delivery System (KDS) are customizing advancement by giving applicable advanced courses for educators. Innovation encourages coordinated effort and training among instructors. Edconnective and Edthena, for instance, permit instructors to transfer video-recorded talks for conversation. Improved technology like Innova in the closed-loop system is a mixed learning approach, where singular PC based learning is subsumed with educator-led collaborative learning sessions. Institutional computerized Massive Open Online Courses (MOOC) systems like the European School net Academy are utilized to sort out STM courses to give educators, school advisors and vocation counsels with assets and thoughts to build students' enthusiasm for STM subjects and professions. Students can likewise be straightforwardly drawn in through MOOC or other online stages, offering seminars on STM themes. The Microsoft Imagine Academy unites the web and face-to-face training to enable learning on principal innovation aptitudes, yet also

\section{Digital and Adaptive Content}

Advanced instructional materials are effectively versatile. A trifling case of a versatile computerized asset for instance, is an exercise provided by the teacher using MS word (Adesoji et al., 2019). In any case, off-the-shelf instructional software as indicated by UNESCO (instructive projects, which are fit to be utilized by students without the educator doing anything to them) are normally closed and not adaptive (Devlin, 2011). Instructing and learning strategies, and not just substance, is versatile gratitude to instructional innovation (Tomte et al., 2019). ICT can supplement existing and rising academic methodologies, for example, a venture based, experiential, request based and versatile learning strategies (Dziabenko et al., 2013). Likewise, some instructive items are designed with customized and versatile substance and educational programs. This instructive item conveys separated learning with one-on-one PC-based learning, which is tailored to individual student needs, frequently utilized adequately with mixed learning approaches blending face to face and online instruction (Irwin, 2014). As per Karampiperis and Sampson (2005), current 
digital courses can be versatile in a manner that attracts students and researchers toward the path of learning, show progress with structures dependent on the utilization of a choice model that gauges the appropriateness of learning assets for a focus on student.

\section{Example of tools}

Computerized libraries are in their youthfulness and in a period of reevaluating into an increasingly versatile and intelligent asset of the community they serve. They ought to be collaborative, permitting students and teachers to contribute information to the library either effectively through explanations, audits, or latently through their examples of asset usage. The adaptive learning platform called Knewton puts achievement within reach for students and researchers using adaptive technologies. Dream-Box

Learning Math and GeoGebra offer math education with PC or tablet, while FluidMath helps students all the more to effectively envision and work with equations and functions. Khan Academy is a spearheading advanced learning association in K-12 instruction, with an enormous scope of STM versatile substance. Online conditions have gotten increasingly intricate throughout the years because of higher transfer speed, accessibility, and innovation, including the development of monstrous multiplayer web-based imaging games. Good examples of these web-based imaging games are Minecraft and World of Warcraft. Numerous virtual and remote research facilities such as Drosophila Virtual Lab and Go-Lab which are used for experiments with digital fruit flies and remote access tests and virtual scenarios using real data respectively are accessible for schools and advanced education students.

Interactive simulations and game-based programs like ST-Math builds up students' natural comprehension of numerical ideas. The Glass-Lab has adapted the famous SimCity PC game for teaching. Finally, 'computer games are an ideal method to teach mathematics' says Stanford Mathematician, K. Devlin (the originator of Inner-Tube games) (Langworthy, 2014).

\section{COMPUTER LITERACY AMONG} STM TEACHERS IN COLLEGES OF EDUCATION IN NIGERIA

STM education in colleges of education is training that gets ready students at different levels, from a trade to a lifelong craft. The STM instruction program has been a necessary piece of national improvement strategy globally and has prompted the acquisition of scientific knowledge and skills. Teaching and 
learning of specialized subjects require the commitment of students in a practical classroom exercise, particularly with the use of ICT instruments. STM instruction is designed to make ready students' ability to perform practicals that can be an entryway to profitable work after graduation. The purpose of STM instruction is to improve individual capability and human asset advancement. As indicated by the constructivist theory, learning is said to have occurred when students can effectively associate learning procedure to world problems. The educator is required to help the students to develop information through the instructing procedure by utilizing critical thinking and inquisitive technique as opposed to emptying information into passive learners.

Nigeria as a growing nation is putting forth an attempt to line up with the developed nations in the introduction of ICT in schools to improve traditional techniques. The National Policy on Education (2004) of the Federal Government of Nigeria stressed that no country can transcend the nature of its educator. Therefore, the instructors who are the vehicle through which this accomplishment can be acknowledged should be all-around educated in the use of ICT tools. The learning task which instructors open to students, help scaffold and bit by bit develop their comprehension of new ideas.

Research conducted by Oso (2015) demonstrated PC education among educators of Kogi State Technical and Vocational Colleges. An engaging review configuration is embraced for the examination. The populace comprised of every single specialized school instructor in Kogi State. The sample size is comprised of 50 specialized professional and instructive educators encouraging STM subjects. 25 items were used as an instrument for the survey. The survey was separated into three segments. The first segment comprises demographic information of the respondents, while segment $\mathrm{B}$ deals with the availability of ICT equipment. Segment $\mathrm{C}$ analyzed ICT proficiency and use. The dependability instrument was discovered through a test-retest strategy utilizing the Pearson Product Moment Correlation. A coefficient of 0.68 was acquired. The survey was carried out under the authority of the school management. Enlightening insights of the rate and recurrence checks were utilized to address the examination questions. The result obtained from that study showed a description of the type of facilities available in the area under study. Computers, computer laboratories, and internet facilities give high frequencies in the number of facilities not available in 
most institutions under study. This implies that computers and computer laboratories which are the core ICT tools needed for STM teachers are not inadequate supply. Another result from the study showed the level of utilization of ICT tools in this area. The result shows that only the projector $(80 \%)$ is frequently used, while computers and educational software are not always used in teaching students. Going by these results, it is obvious that an inadequate number of computers have a direct effect on usage. Another possibility is PC proficiency among STM teachers. PC proficiency of STM teachers as indicated in the study showed that teachers in the area under study are more comfortable using traditional methods of teaching STM subjects. Only $28 \%$ of these teachers can operate computer systems.

Deebom and Goma (2018) also carried out a study on the use of ICT facilities among technical educators in Rivers State. The sample size used for this study was 79 . Results from the study also showed the level of ICT utilization. The study concluded that, though technical educators in the state are proficient in the use of computers, there is poor utilization of this knowledge in the teaching of STM subjects in the state. This implies that, there are no adequate measures put in place to ensure that technical educators in the state compulsorily use ICT tools in teaching science, technology, and mathematics.

Another study conducted by Onu and Ezhim (2019) on the utilization of ICT facilities in north-central Nigeria showed that ICT facilities are inadequate in this zone. The unavailability of these facilities is likely connected to the inappropriate utilization of funds allocated to the governments of these states for the project (Onu and Ezhim, 2019). The study further showed a mean score between 2.55 and 4.00 and Standard Deviation ranging between 0.31 and 1.07 on the utilization of ICT tools by teachers. The mean score from the result obtained was above the benchmark set for the study, which was 2.50 (Onu and Ezhim, 2019). This agreed with their hypothesis that says there are great challenges in the utilization of ICT facilities (Onu and Ezhim, 2019). Lack of use of these facilities implies that there is low PC proficiency among teachers in the various states of North-Central Nigeria

The next section of this study will give a descriptive analysis of the survey we carried out in some of the colleges of education in the north-central part of Nigeria.

\section{METHODOLOGY}

To have an in-depth understanding of the level of computer literacy among STM 
teachers in colleges of education in Nigeria, study thus; they form the populace for this this work surveyed five different colleges of research. These institutions are Federal education in north-central Nigeria. The College of Education, Kotagora, Niger main focus of the survey was to find out the availability of ICT tools. The study differs from other studies carried out as more focus is given to software tools required for the learning and teaching of STM subjects. Major software tools deliberated in Section 2.1 of this work form part of the questions that make up the survey.

\section{Study design}

This work examined the level of PC proficiency among STM teachers in the study area. The study intended to ascertain that ICT tools needed for teaching and learning STM courses are available, in use and to know whether STM teachers are proficient in the use of these tools.

State; Federal College of Education, Okene, Kogi State; Federal College of Education, Pankshin, Plateau State; College of Education, Akwanga, Nasarawa State and College of Education, Zuba, FCT - Abuja.

3. Study instrument

Data for this study were gathered through a poll structure using google form. The study is a simple descriptive analysis from data obtained from respondents. The questionnaire has two sections. Section 'A' concerned distribution of responses based on their various institutions. Section 'B' has to do with three major issues of ICT tools availability, usage, and teachers' proficiency.

2. Population and Sample Size

A total of 134 teachers from five (5)

4. Results

The results for this work are presented colleges of education in north-central in Tables $1-4$.

Nigeria were used to provide data for this

Table 1: Institutions of respondents

\begin{tabular}{|l|l|c|c|}
\hline S/N & \multicolumn{1}{|c|}{ Institution } & $\begin{array}{c}\text { Number of } \\
\text { respondents }\end{array}$ & $\begin{array}{c}\text { \% of } \\
\text { respondents }\end{array}$ \\
\hline 1. & $\begin{array}{l}\text { Federal College of Education, Kontagora, Niger } \\
\text { State }\end{array}$ & 43 & 32.09 \\
\hline 2. & $\begin{array}{l}\text { Federal College of Education, Okene, Kogi } \\
\text { State }\end{array}$ & 19 & 14.18 \\
\hline 3. & $\begin{array}{l}\text { Federal College of Education, Pankshin, } \\
\text { Plateau State }\end{array}$ & 33 & 24.62 \\
\hline 4. & $\begin{array}{l}\text { College of Education, Akwanga, Nasarawa } \\
\text { State }\end{array}$ & 22 & 16.42 \\
\hline 5. & College of Education, Zuba, FCT - Abuja & 17 & 12.69 \\
\hline & \multicolumn{1}{|l|}{} & $\mathbf{1 0 0}$ \\
\hline
\end{tabular}


The result from Table 1 shows that majority of population size was from the College of Education, Kontagora, Niger State with $32.09 \%$. Though the majority of of the country.

Table 2: Number of ICT facilities available in the surveyed area.

\begin{tabular}{|c|c|c|c|c|c|c|c|}
\hline \multirow[t]{2}{*}{$\begin{array}{l}\mathbf{S} / \\
\mathbf{N}\end{array}$} & \multirow[t]{2}{*}{ ICT tools } & \multicolumn{2}{|c|}{$\begin{array}{c}\text { Facilities are } \\
\text { adequate }\end{array}$} & \multicolumn{2}{|c|}{$\begin{array}{c}\text { Facilities not } \\
\text { sufficient }\end{array}$} & \multicolumn{2}{|c|}{$\begin{array}{c}\text { No } \\
\text { facilities }\end{array}$} \\
\hline & & Freq & $\%$ & Freq & $\%$ & Freq & $\%$ \\
\hline \multicolumn{8}{|c|}{ Hardware tools } \\
\hline 1. & $\begin{array}{l}\text { Computer Systems } \\
\text { convenient tables \& chair }\end{array}$ & 23 & 17.2 & 102 & 76.1 & 9 & 6.7 \\
\hline 2. & $\begin{array}{llll}\begin{array}{l}\text { Internet facilities and stable } \\
\text { network }\end{array} & & \\
\end{array}$ & 15 & 11.2 & 22 & 16.5 & 97 & 72.3 \\
\hline 3. & $\begin{array}{l}\begin{array}{l}\text { Interactive whiteboard (Electronic } \\
\text { board) }\end{array}\end{array}$ & 08 & 6.0 & 83 & 61.9 & 43 & 32.1 \\
\hline \multicolumn{8}{|c|}{$\begin{array}{ll}\text { Software tools } \\
\end{array}$} \\
\hline 4. & \multicolumn{7}{|l|}{ Collaborative tools } \\
\hline a. & Padlet for teachers & 0 & 0 & 0 & 0 & 134 & 100 \\
\hline b. & $\begin{array}{ll}\text { Skype for interactive/ } \\
\text { collaborative learning }\end{array}$ & 05 & 3.8 & 14 & 10.4 & 115 & 85.8 \\
\hline 5. & \multicolumn{7}{|l|}{ Online learning tools } \\
\hline a. & $\begin{array}{l}\text { TeachScape and Knowledge } \\
\text { Delivery System (KDS) }\end{array}$ & 04 & 3.0 & 0 & 0 & 130 & 97.0 \\
\hline b. & $\begin{array}{l}\text { Massive Open Online Courses } \\
\text { (MOOC) systems }\end{array}$ & 09 & 6.7 & 19 & 14.2 & 106 & 79.1 \\
\hline 6. & \multicolumn{7}{|l|}{ Digital and Adaptive contents } \\
\hline a. & $\begin{array}{l}\text { Adaptive software and simulation } \\
\text { systems like Dream Box Learning } \\
\text { Maths, ST-Maths and Geo Gebra }\end{array}$ & 17 & 12.8 & 0 & 0 & 114 & 85.2 \\
\hline b. & $\begin{array}{l}\text { Virtual and remote research } \\
\text { facilities like Drosophila Virtual } \\
\text { Lab and Go-Lab }\end{array}$ & 17 & 12.8 & 0 & 0 & 114 & 85.2 \\
\hline
\end{tabular}

Table 2 gives a detailed description of the facilities available in the area under study. While hardware tools are considerably available, the result from this table shows that most of the institutions have no software tools necessary for teaching and learning STM subjects installed in their computer systems.

respondents were from Niger State, the research still covers a good population size from other states in the north-central zone 
network also constitutes a major setback to the usage of most of these tools.

Table 3:- Usage of ICT tools by teachers in the area under study.

\begin{tabular}{|l|l|c|c|c|c|}
\hline S/N & \multicolumn{1}{|c|}{$\begin{array}{c}\text { Whether teachers use ICT facilities to } \\
\text { teach students }\end{array}$} & \multicolumn{2}{c|}{ Yes } & \multicolumn{2}{c|}{ No } \\
\hline & & Freq & \% & Freq & \% \\
\hline 1. & Computer Systems & 36 & 26.9 & 98 & 73.1 \\
\hline 2. & Internet facilities and stable network & 27 & 20.1 & 107 & 79.9 \\
\hline 3. & Interactive whiteboard (Electronic board) & 73 & 54.5 & 61 & 45.5 \\
\hline 4. & Collaborative tools & 0 & 0 & 134 & 100 \\
\hline 5. & Online learning tools & 17 & 12.7 & 117 & 87.3 \\
\hline 6. & Digital and Adaptive contents & 0 & 0 & 134 & 100 \\
\hline
\end{tabular}

Table 4:- Level of PC proficiency among teachers in the teaching and learning of STM subjects.

\begin{tabular}{|l|l|c|c|c|c|}
\hline S/N & \multicolumn{1}{|c|}{$\begin{array}{c}\text { Proficiency level in the use of ICT } \\
\text { facilities }\end{array}$} & \multicolumn{1}{c|}{ Skillful } & \multicolumn{2}{c|}{ Not skillful } \\
\hline & \multicolumn{1}{|c|}{ Freq } & \% & Freq & \% \\
\hline 1. & I can teach students using a computer system & 102 & 76.1 & 32 & 23.9 \\
\hline 2. & $\begin{array}{l}\text { I know how to use an interactive whiteboard } \\
\text { to engage students in learning }\end{array}$ & 75 & 56.0 & 59 & 44.0 \\
\hline 3. & $\begin{array}{l}\text { I can use Padlet to interact with students on a } \\
\text { particular topic, allow for live question bank, } \\
\text { and gather students' work. }\end{array}$ & 0 & 0 & 134 & 100 \\
\hline 4. & $\begin{array}{l}\text { I have an idea of at least one online learning } \\
\text { tool and I can use it effectively in teaching } \\
\text { science, technology, or mathematics. }\end{array}$ & 41 & 30.6 & 93 & 69.4 \\
\hline 5. & $\begin{array}{l}\text { I have used and can effectively work with } \\
\text { one of these digital and adaptive contents - } \\
\text { Dream Box Learning Math, Geo Gebra, } \\
\text { Drosophila Virtual Lab, Go-Lab, ST-Math }\end{array}$ & 5 & 3.7 & 129 & 96.3 \\
\hline 6. & $\begin{array}{l}\text { Apart from the hardware and software tools } \\
\text { mentioned above, I have used and effectively } \\
\text { can work with at least a tool to engage } \\
\text { students in teaching and learning of science, } \\
\text { technology, and mathematics }\end{array}$ & 37 & 27.6 & 97 & 72.4 \\
\hline
\end{tabular}

It is obvious from Table 4 that though many teachers can teach using computer systems, lack of exposure to basic software tools needed for effective teaching and learning is a major challenge. None of the teachers in the area under study can use Padlet to engage students. $96.3 \%$ of the respondents cannot use any digital and adaptive content for teaching STM subjects. The result from this table implies that the provision of hardware tools alone cannot solve the issue of PC proficiency among teachers in colleges of education in Nigeria. The government will need to train and re-train 
teachers to be able to keep pace with new tools needed for teaching and learning STM subjects.

\section{SUMMARY OF FINDINGS}

From the discoveries in section 4.0, we can reason that there is a low degree of PC proficiency among STM instructors in colleges of education. The purposes behind this incorporate the following:-

\section{Unskillful educators: - The} examination uncovered that instructors didn't utilize PCs, simulation, digital and adaptive contents in instructional conveyance. Likewise the educators are not skillful in the utilization of ICT facilities in teaching STM subjects. Consequently, they can best be described as computer illiterates. This implies that a conventional technique for educating is still utilized in instructional conveyance in most of these vocational and technical colleges. Little marvels that ICT is still in its rising stage in the teaching of STM subjects.

\section{Inadequate ICT facilities to improve} PC proficiency:- The examination uncovered that ICT facilities like PCs, PC labs, networks, and electronic boards are not satisfactorily accessible in the schools. Regardless of whether the educators were happy to utilize these tools in teaching STM subjects, the inaccessibility of the tools has a way of upsetting them. The investigation supports the discoveries of Okwudishu (2005), who focused on the inaccessibility of some ICT facilities in schools, which hamper instructors' use of the devices and capacity to stay informed concerning new ICT apparatuses. Okwudishu (2005) sees that, $90 \%$ of Nigerian vocational and technical colleges have no PC and a considerable lot of the study halls are without ICT facilities. Many of these colleges do not have practical web facilities.

3. Phobia for Computers: - Computer fear has all the earmarks of being a mental marker for PC use and utilization in educating and learning STM subjects. It influences educators of colleges of education in the usage of PCs for showing logical ideas. This finding concurs with Alabi (2015) submission that, the degree of PC proficiency has a noteworthy relationship on the level of computer phobia among educators of colleges of education in Nigeria.

4. Access to PCs and the web:- The study as presented in Table 3 additionally uncovered that instructors don't have access to computers and in most times, no stable network that can effectively aid in teaching. The much an educator can 
know and instruct relies upon how students to be involved in interactive and frequently he/she has access to ICT collaborative learning that will help them equipment. This factor has brought about the degree of PC proficiency among STM instructors of colleges of education in Nigeria.

5. ICT tools for STM education:- ICT devices for STM education talked about in section 2.1 are inadequate and in most cases unavailable in many colleges of education in Nigeria. These instruments are intended to help in the teaching and learning of science, technology, and mathematics. The absence of these instruments in colleges of education in Nigeria is that as it may, affects the degree of PC education among STM instructors.

\section{CONCLUSION}

The discoveries of this investigation have demonstrated that colleges of education in Nigeria have a low degree of $\mathrm{PC}$ education in instructing and learning of STM subjects. The assets were found not to be sufficiently accessible and the educators have no instructive aptitude in the utilization of ICT apparatuses for STM training henceforth, there is a skill gap. The high PC proficiency level must be conceivable through instructors' viable and proficient utilization of ICT tools in their instructional conveyance. This will attract acquire the needed skills to be self-reliant. Moreover, the perception has demonstrated that the Nigerian government has not given STM education the consideration it truly merits. This is because of the adjustments in the world's economy accentuation, which has moved from preparing for a lifelong profession to preparing for PCs and data innovation. Nigerian graduates were scored low in specialized abilities by The World Bank Report of Guardian News Paper (2001). It revealed that Nigerian graduates are lack capacity and don't have essential abilities subsequently fit for the world's labor market. The mix of visual learning and innovations can adequately help to improve students' understanding and grow their mind-set. This will give rich learning encounters to students to participate in. The problem-solving exercises have shown that students are not only engaged in learning, but it stimulates them to want to learn more through collaborative tools. Therefore, teachers need to keep pace with the software tools needed to engage these students. This will enhance classroom communicative interactions involving an apprenticeship kind of learning; planning students for occupations at different levels, from art/trade to a professional position in different fields. The style can likewise build 
students' intellectual level, which perpetually reflects in the knowledge acquired in STM subjects.

\section{RECOMMENDATION}

From this study, it is obvious that $\mathrm{PC}$ proficiency among STM educators in colleges of education in Nigeria is low. This demonstrated that teaching and learning of science, technology, and mathematics in colleges of education can only be linked to traditional strategy for information conveyance with no effect on the job of PC proficiency. To be side by side with current patterns in teaching and learning of STM subjects for intuitive, dependable, assorted application and to enable a child to learn in a manner and a pace which suits his/her capacities, the accompanying proposals ought to be thought of.

1. The government ought to give enough funds to furnish the schools with important ICT assets/instruments for STM subjects.

2. Teachers ought to likewise be prepared on the utilization of ICT assets to empower them to stay informed concerning the new advancement in the field of specialized training. This will assist them in building up the imperative ICT abilities which will give them the fundamental handy and practical information on ICT asset usage fully expecting to incorporate them in their teaching and learning collection.

3. There is a need for a supportive policy environment invigorated with an unmistakably enunciated reason for access to, and utilization of PCs and the web in colleges of education in Nigeria.

4. Colleges of education ought to build up their initiatives for setting up and utilizing PC labs such that every student will have access to a PC during classroom teaching. This can be achieved with effective time management for the use of computer laboratories.

\section{REFERENCES}

Adesoji, F. A., Omilani, N. A., and Francis, O. A. (2019). Teacher variables and school location as predictors of chemistry teacher's awareness of ethnoscience practices. Journal of Education, Society and Behavioural Science, 31(1), 1-17.

Alabi, O. O. (2015). An assessment of the level of computer literacy and phobia among private secondary school Principals in Kaduna North Local Government Area of Kaduna State, Nigeria. Journal of Biology, Agriculture and Healthcare, 1(6), 1828.

Balanskat, A., Blamire, R., and Kefala, S. (2006). A review of studies of ICT impact on schools in Europe. European Schoolnet for the European Communities. Retrieved from https://ictedupolicy.org/fr/system/files /rapp doc254 en.pdf on 2nd April, 2020. 
Barak, W. (2014). Closing the gap between attitudes and perceptions about ICTenhanced learning among pre-service STEM teachers. Journal of Science Education Technology, 23(2), 1-14.

Berenfeld, R., and Yazijian, J. (2010). Global lab: harnessing the cloud \& social networking for $\mathrm{K}-12$ science learning since 1991. In: Gibson D, Dodge B (eds) Proceedings of society for information technology and teacher education international conference. AACE, Chesapeake, pp 3544-3547.

Correll, P. (2015). IoT in education: Exploring the evolving potential for digital learning. Edtech Digest. Retrieved from https://edtechdigest.wordpress.com/2 015/05/13/iot-in-education/ on $3^{\text {rd }}$ March, 2020.

Davis, H. A. (2003). Conceptualizing the role and influence of student-teacher relationships on children's social and cognitive development. Educational Psychologist, 38(4), 207-234.

Dawson, K. (2012). Using action research projects to examine teacher technology integration practices, Journal of Digital Learning in Teacher Education, 28 (3), 23-38.

Deebom, M. T. and Goma, O. T. (2018). Utilization of Information Communication and Technology for sustainable manpower institutions in Rivers State Nigeria. International Journal of Innovative Information Systems and Technology Research, 6 (2), 4858.

Devlin, K. (2011). Mathematics education for a new era: Video games as a medium for learning. CRC Press, Taylor and Francis. $1^{\text {st }}$ Edition,

Dziabenko, O., Orduna, P., Garcia-Zubia, J. (2013). Remote experiments in secondary school education. 2013 IEEE Frontiers in Education Conference (FIE) pp. 1760-1764. Retrieved from https://www.computer.org/csdl/proce edings/fie/2013/9999/00/06685140.pd f on 30th March, 2020.
Haigh, R. W. (1985). Planning for computer literacy. The Journal of Higher Education. 56(2), 161171. doi: $\underline{10.2307 / 1981664}$. JSTOR $\underline{19}$ 81664.

Irwin, J. L. (2014). The RepRap 3-D printer revolution in STEM education. 121st ASEE Annual Conference \& Exposition. Retrieved from http://www.asee.org/file server/paper s/attachment/file/0004/4989/asee repr ap paper final1.pdf on $6^{\text {th }}$ April, 2020.

Karampiperis, P. and Sampson, D. (2005). Adaptive learning resources sequencing in educational hypermedia systems. Journal of Educational Technology \& Society, 8(4), 128-147.

Langworthy, M. (2014). Vision for anytime anywhere learning for all. Transformation Framework, Microsoft in Education. Retrieved from http://tinyurl.com/ngelbsw on 5th April, 2020.

Mary, A. R. (2007). Perceptions of technological literacy among Science, Technology, Engineering and Mathematics Leaders. Journal of Technology Education, 19(1), 35-52.

National Policy on Education (2004) FRN.

Necdet, K. (2010). Computer literacy levels of teachers. Social and Behavioural Sciences, Elsevier Publication, doi:10.1016/j.sbspro.2010.03.374.

Okwudishu, C. H. (2005). Awareness and use of Information and Communication Technology (ICT) among village secondary school teachers in Aniocha South Local Government. Unpublished article.

Onu, F. M. and Ezhim, I. A. (2019). Utilization of ICT facilities for enhancing instructional delivery of Agricultural Science in Nigeria secondary schools. Library Philosophy and Practice (e-journal, 2646.

Oso, S. O. (2015). ICT Literacy among Vocational and Technical Education 
Teachers in Kogi State Technical and Vocational Colleges: Skill Gaps. European Centre for Research Training and Development, 3(5), 2130.

Satharasinghe, A., (2006). Census on Computer Literacy of Teachers. Retrieved from http://www.statistics.gov.lk/education IIT\%20Literacy\%20Survey/index.htm on 4th April, 2020.

The world Bank Report in the Nigerian Guardian News Paper Feb 19 (2001).
Tomte, C. E., Fossland, T., Aamodt, P. O. and Degn, L. (2019). Digitalization in higher education: Mapping institutional approaches for teaching and learning. Quality in Higher Education, Taylor \& Francis, 25(1), 98-114.

Ulmer, G. L. (2003). Internet Invention: From literacy to electracy. New York: Longman. 